\title{
PENGARUH PEMBERIAN JUS PARE (Momordica Charantia L.) DAN JUS JERUK NIPIS (Citrus Aurantifolia) TERHADAP KADAR KOLESTEROL TOTAL TIKUS SPRAGUE DAWLEY HIPERKOLSTEROLEMIA
}

\author{
Aresta Wulan Purnamasari, Muflidah Isnawati" \\ Program Studi Ilmu Gizi Fakultas Kedokteran Universitas Diponegoro \\ Jl.Dr.Sutomo No.18, Semarang, Telp (024) 8453708, Email : gizifk@ undip.ac.id
}

\begin{abstract}
Background: Hypercholesterolemia is a major and an independent risk factor of cardiovascular disease. Lowering total cholesterol level is one of main treatment strategy of cardiovascular disease. Bitter melon and lime fruit are potencial for lowering total cholesterol level. This study aims to analyze the effect of bitter melon juice, lime juice, and a combination both of fruits on lowering total cholesterol level.

Methods: This research was true experimental using pre-post test randomized control group design. Samples were 28 hypercholesterolemic male Sprague Dawley rats divided into 4 groups. During 4 weeks intervention, control group fed only standard food, group 1 (P1) was fed standard food and bitter melon juice $2 \mathrm{ml} /$ day, group 2 (P2) was fed standard food and lime juice $2 \mathrm{ml} /$ day and group $3(P 3)$ was fed standard food and combination of bitter melon+lime juice $4 \mathrm{ml} /$ day. Levels of total cholesterol were analyzed using CHOD-PAP method. Data were analyzed by paired ttest and one-way ANOVA.

Results: There were reduction of total cholesterol level after administration of bitter melon juice (22,51\%), lime juice $(28,93 \%)$, and a combination of both fruits $(24,04 \%)(p<0.05)$. However, there were no difference means of total cholesterol level between control group and treatment groups significantly $(p>0,05)$

Conclusion: There were no difference effect of bittermelon juice, lime juice, combination of both fruits on lowering total cholesterol level in hypercholesterolemic rats.
\end{abstract}

Key words : bitter melon; lime; total cholesterol; hypercholesteromia

\section{ABSTRAK}

Latar Belakang : Hiperkolesterolemia merupakan faktor utama dan faktor risiko independen penyakit kardiovaskuler. Penurunan kolesterol total merupakan salah satu strategi dalam terapi penyakit kardiovaskuler. Buah pare dan jeruk nipis memilki potensi menurunkan kolesterol total. Penelitian ini bertujuan untuk mengetahui pengaruh jus pare, jus jeruk nipis dan kombinasi kedua buah dalam menurunkan kolesterol total.

Metode : Penelitian ini merupakan true experimental dengan rancangan pre-post test randomized control group design. Sampel terdiri dari 28 tikus jantan Sprague Dawley hiperkolesterolemia yang dibagi menjadi 4 kelompok. Intervensi dilakukan selama 14 hari dengan kelompok kontrol hanya diberi pakan standar, perlakuan 1 (P1) diberi jus pare $2 \mathrm{ml} / \mathrm{e}$ kor/hari, perlakuan 2 (P2) diberi jus jeruk nipis $2 \mathrm{ml} /$ ekor/hari dan perlakuan 3 (P3) diberi kombinasi jus pare dan jus jeruk nipis sebanyak $4 \mathrm{ml} / \mathrm{ekor} / \mathrm{hari}$. Kadar kolsterol total dianalisis dengan metode CHOD-PAP. Data dianalisis dengan uji Paired t-test dan one way Anova.

Hasil : Penelitian ini menunjukkan terjadi penurunan kolesterol total setelah pemberian jus pare (22,51\%), jus jeruk nipis $(28,93 \%)$ dan kombinasi jus pare+jeruk nipis $(24,04 \%)$ ( $p<0,05)$. Namun tidak terdapat perbedaan rerata perubahan kadar kolesterol total antara kelompok kontrol dan perlakuan dengan $p=0,105(p>0,05)$

Simpulan : Tidak terdapat perbedaan pengaruh pemberian pare, jus jeruk nipis dan kombinasi jus pare+jeruk nipis terhadap penurunan kolesterol total tikus hiperkolesterolemia.

Kata Kunci : pare; jeruk nipis; koelsterol total; hiperkolesterolemia

\section{PENDAHULUAN}

Hiperkolesterolemia merupakan gangguan metabolisme lemak yang ditandai dengan peningkatan kadar kolesterol total hingga $\geq 240$ $\mathrm{mg} / \mathrm{dl}{ }^{1,2}$ Tingginya kadar kolesterol dalam darah merupakan faktor utama dan faktor risiko independen terbentuknya plak aterosklerosis yang menyebabkan penyakit kardiovaskuler. ${ }^{2,3}$ Penyakit kardiovaskuler merupakan penyebab utama kematian baik di negara maju maupun berkembang. ${ }^{3,4}$ Jumlah kematian akibat penyakit kardiovaskuler terutama penyakit jantung dan stroke diperkirakan akan mencapai 23,3 juta jiwa pada tahun $2030 .{ }^{4}$

Pengendalian kadar lipid melalui penurunan kolesterol total sampai batas yang dianjurkan merupakan strategi ideal dan salah satu target utama pada terapi penyakit kardiovaskuler. ${ }^{5-7}$ Pengelolaan hiperkolesterolemia dapat dilakukan melalui upaya nonfarmakologis dengan perubahan pola hidup sehat dan pengaturan diet dengan membatasi konsumsi asupan kolesterol dan lemak jenuh serta

\footnotetext{
${ }^{*}$ Penulis Penanggungjawab
} 
meningkatkan konsumsi buah-buahan dan sayuran $^{6,8}$

Pare (Momordica charantia L.) dan jeruk nipis merupakan buah memiliki potensi menurunkan kadar kolesterol total. Pare lebih dikenal sebagai tanaman antidiabetik dan digunakan sebagai terapi alami bagi penderita diabetes, memiliki aktivitas anti inflamasi dan anti kanker. Efek hipokolesterolemik buah pare berkaitan dengan kandungan zat fitokimiawi dalam buah pare antara lain saponin, vitamin $\mathrm{C}$ dan lutein pada kulit pare. ${ }^{9,10}$ Dalam 100 gram buah pare segar mengandung vitamin $\mathrm{C}$ sebesar $84 \mathrm{mg}$, dan lutein $170 \mathrm{mcg}$ yang lebih tinggi dibandingkan sayuran lain seperti wortel dan bayam. ${ }^{10}$ Pemberian jus pare $2 \mathrm{ml}$ selama 15 hari dapat menghambat kenaikan kadar kolesterol total tikus wistar yang diberi pakan tinggi lemak . ${ }^{11}$ Salah satu mekanisme hipokolesterolemik buah pare yaitu dengan meningkatkan aktivitas enzim cholesterol $7 \alpha$ hydroxylase (CYP7A1) dalam mengkonversi kolesterol menjadi asam empedu yang selanjutnya dapat diekskresikan dari tubuh. ${ }^{12}$

Jeruk nipis merupakan salah satu jenis jeruk yang sering dikonsumsi masyarakat. Selain vitamin $\mathrm{C}$, kandungan flavonoid utama dalam jeruk nipis yaitu hesperidin dapat membantu menurunkan kadar kolesterol total. ${ }^{13,14}$ Dalam 100 gram jeruk nipis mengandung vitamin $\mathrm{C} 63 \mathrm{mg}$ dan hesperidin sebanyak 15,64 mg yang lebih tinggi dibandingkan jeruk manis dan lemon. ${ }^{15}$ Sebuah penelitian pada kelinci yang diberi pakan tinggi kolesterol dan jus jeruk nipis $5 \mathrm{ml}$ selama 60 hari menunjukkan adanya perbedaan rerata kolesterol total secara bermakna antara kelompok perlakuan dan kontrol yaitu $882 \pm 194,4 \mathrm{mg} / \mathrm{dl}$ dan $941,1 \pm 224,6 \mathrm{mg} / \mathrm{dl} .{ }^{16}$ Hesperidin dapat menghambat kerja enzim 3hydroxy-3-methylglutaryl coenzim A-reductase sehingga dapat menekan sintesis kolesterol oleh hati dan dapat meningkatkan konsentrasi reseptor LDL. ${ }^{17}$

Mekanisme hipokolesterolemik pada buah pare dan jeruk nipis tersebut diduga dapat bekerja lebih optimal apabila dikombinasikan. Kombinasi jus pare dan jeruk nipis ini diharapkan mampu meningkatkan sinergisitas efek hipokolesterolemik yang lebih signifikan. Penelitian mengenai efek hipokolesterolemik kombinasi jus pare+jeruk nipis dalam menurunkan kadar kolesterol pada tikus maupun manusia belum pernah dilakukan. Penelitian ini bertujuan untuk mengetahui pengaruh pemberian jus pare, jus jeruk nipis, kombinasi jus pare+jeruk nipis terhadap penurunan kadar kolesterol total tikus Sprague dawley hiperkolesterolemia. Tikus Sprague dawley dengan jenis kelamin jantan dipilih karena memiliki kondisi biologis tubuh lebih stabil karena tidak terpengaruh hormon estrogen seperti tikus betina dan responsif terhadap diet hiperkolesterolemia tetapi memiliki kestabilan kadar fosfolipid yang baik. ${ }^{19}$

\section{METODE PENELITIAN}

Penelitian ini merupakan penelitian eksperimental laboratorik sesungguhnya (true experimental) dengan rancangan pre-post test randomized control group design yang dilakukan di Laboratorium Fisiologi Hewan Jurusan Biologi Fakultas MIPA Universitas Negeri Semarang (UNNES). Variabel bebas penelitian ini adalah pemberian jus pare, jus jeruk nipis dan kombinasi jus pare dengan jus jeruk nipis dan variabel tergantung adalah kadar kolesterol total tikus coba.

Jumlah sampel penelitian ditentukan dengan metode Federer yaitu 28 tikus jantan galur Sprague Dawley yang diperoleh dari Bagian Farmakologi dan Farmasi Klinik, Fakultas Farmasi, Universitas Gadjah Mada Yogyakarta. Kriteria inklusi sampel adalah tikus usia 6-8 minggu, berat badan 100-150 gram dan kriteria ekslusi adalah penurunan berat bedan sebesar $10 \%$ dari berat badan minggu sebelumnya, tikus mati saat penelitian dan mengalami perubahan perilaku (menolak makan dan lemas). Sampel ditempatkan pada kandang individu, pemeliharaan dan pembersihan kandang dilakukan setiap hari. Aklimatisasi atau tahap adaptasi dilakukan selama 14 hari dengan pemberian pakan standar BR 2 dan minum ad libitum. Pakan standar mengandung air $12 \%$, protein kasar $19-21 \%$, lemak kasar 4-8\%, serat kasar $5 \%$, abu $8 \%$, kalsium $0,9-1,2 \%$, fosfor $0,7-$ $1 \%$, antibiotika. Pakan standar diberikan setiap hari selama penelitian pada semua sampel sebanyak 20 gram/ekor/hari. Sisa pakan ditimbang setiap hari sehingga dapat diketahui jumlah pakan standar yang diasup oleh sampel. Setelah tahap aklimatisasi, pada hari ke-17 mulai dilakukan induksi hiperkolesterolemia dengan penambahan pakan tinggi koletserol yaitu bubur otak sapi melalui sonde sebanyak $2 \mathrm{ml} / \mathrm{ekor} /$ hari selama 14 hari.

Sampel dibagi menjadi 4 kelompok secara acak yang tiap kelompok terdiri dari 6 ekor tikus coba yaitu kelompok kontrol, perlakuan 1(P1), perlakuan (P2), perlakuan $3(\mathrm{P} 3)$. Selama 14 hari intervensi, kelompok kontrol hanya diberi pakan standar, kelompok P1 diberi pakan standar dan jus pare $2 \mathrm{ml} /$ ekor/hari, kelompok $\mathrm{P} 2$ diberi pakan standar dan jus jeruk nipis $2 \mathrm{ml} / \mathrm{ekor} / \mathrm{hari}$, kelompok P3 diberi pakan standar dan kombinasi kedua jus sebanyak $4 \mathrm{ml} / \mathrm{ekor} / \mathrm{hari}$. Pemberian pakan tinggi kolesterol dan intervensi dilakukan dengan sonde 
untuk memastikan semua sampel mendapat jumlah pakan dan intervensi yang direncanakan. Setiap minggu dilakukan penimbangan berat badan sampel sehingga dapat diketahui perubahan berat badan selama penelitian. Selama penelitian tidak ada sampel yang drop out.

Selama penelitian dilakukan pengambilan darah sampel sebanyak 3 kali untuk memeriksa kadar kolesterol total pada serum darah. Pada hari ke 16 dilakukan pengambilan darah I (setelah aklimatisasi) untuk mengetahui kolesterol total awal tikus coba, pengambilan darah II dilakukan setelah induksi hiperkolesterolemia yaitu hari ke-30 untuk memastikan kadar kolesterol total memenuhi kondisi hiperkolesterolemia (kolesterol total > 54 $\mathrm{mg} / \mathrm{dL}$ ) dan pengambilan darah III dilakukan setelah intervensi pada hari ke-46. Darah sampel diambil melalui pleksus retroorbitalis sebanyak 2 $\mathrm{ml} /$ ekor kemudian disentrifuge untuk memisahkan serum dengan darah. Pemeriksaan kadar kolesterol total darah dilakukan dengan metode Cholesterol Oxidase Phenol Aminoantipyrin (CHOD-PAP) di Balai Laboratorium Kesehatan Provinsi Jawa Tengah.

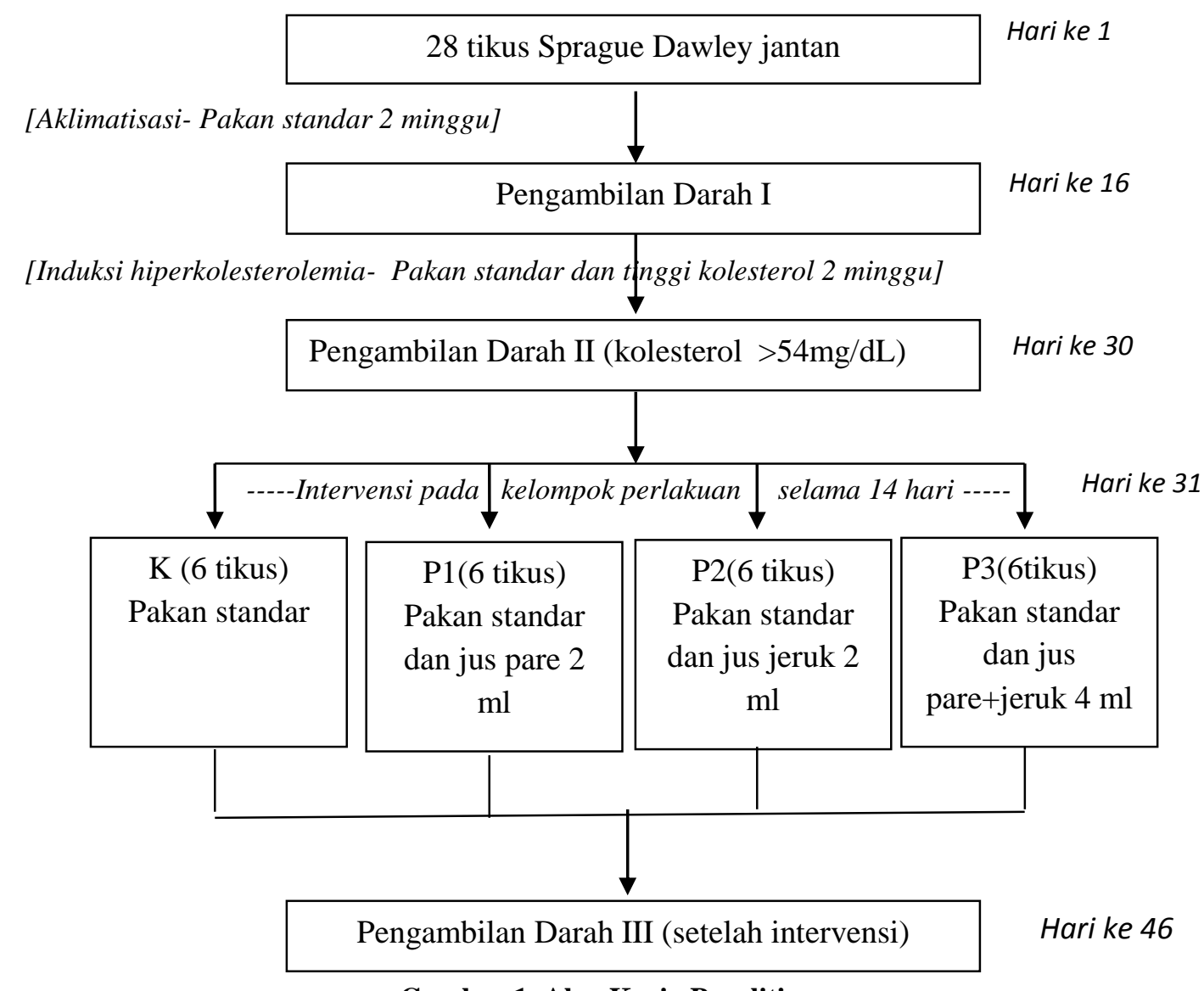

Gambar 1. Alur Kerja Penelitian

Buah pare jenis pare bodas dan jeruk nipis yang digunakan berasal dari Pasar Bulu Kota Semarang. Jus pare dibuat dari \pm 75 gram daging buah pare (Momordica charantia L.) yang dipisahkan dari bijinya kemudian diambil sarinya menggunakan alat juicer tanpa penambahan air, sehingga diperoleh jus pare sebanyak $\pm 40 \mathrm{ml}$. Jus jeruk nipis yang digunakan adalah campuran air perasan jeruk nipis beserta bulir-bulirnya sebanyak $\pm 40 \mathrm{ml}$ dari 90 gram jeruk nipis. Kombinasi jus terdiri dari jus pare+jeruk nipis yang telah dicampur terlebih dahulu dengan perbandingan 1:1. Jus pare, jeruk nipis dan kombinasi jus pare+jeruk nipis yang digunakan adalah jus segar yang dibuat setiap hari selama intervensi. Penentuan dosis jus jeruk nipis didasarkan pada penelitian kelinci yang diberi jus jeruk nipis sebesar $5 \mathrm{ml}$ (hesperidin $\sim 0,195 \mathrm{mg}$ ). ${ }^{16}$ Dosis tersebut dikonversi ke dosis untuk tikus coba dan diperoleh dosis sebesar $2 \mathrm{ml}$. Setiap tikus coba pada kelompok perlakuan 2 diberikan jumlah dosis yang sama. Dosis jus pare segar (fresh juice) yang digunakan merupakan hasil konversi dosis anjuran jus pare untuk manusia sebesar $100 \mathrm{ml}$ (dosis anjuran 50-100 ml) ke tikus coba sehingga diperoleh dosis sebanyak 2 ml. ${ }^{19}$ Setiap tikus coba pada kelompok perlakuan 1 memperoleh dosis jus 
pare yang sama. Penentuan dosis juga mempertimbangkan volume lambung tikus yang maksimal hanya $5 \mathrm{ml}^{20}$ Dosis kombinasi jus pare+jeruk nipis merupakan dosis jus pare dan jus jeruk nipis yang telah dicampur dengan perbandingan 1:1 sehingga diperoleh dosis sebesar $4 \mathrm{ml}$.

Data yang diperoleh diuji normalitasnya dengan uji Shapiro Wilk. Untuk mengetahui pengaruh pemberian intervensi dilakukan uji beda paired t-test pada kadar kolesterol total sebelum dan setelah intervensi sedangkan untuk mengetahui perbedaan pengaruh antar kelompok dilakukan uji one way ANOVA.

\section{HASIL}

\section{Perubahan Berat Badan Selama Penelitian}

Perubahan berat badan sampel selama penelitian ditunjukkan pada grafik di bawah ini

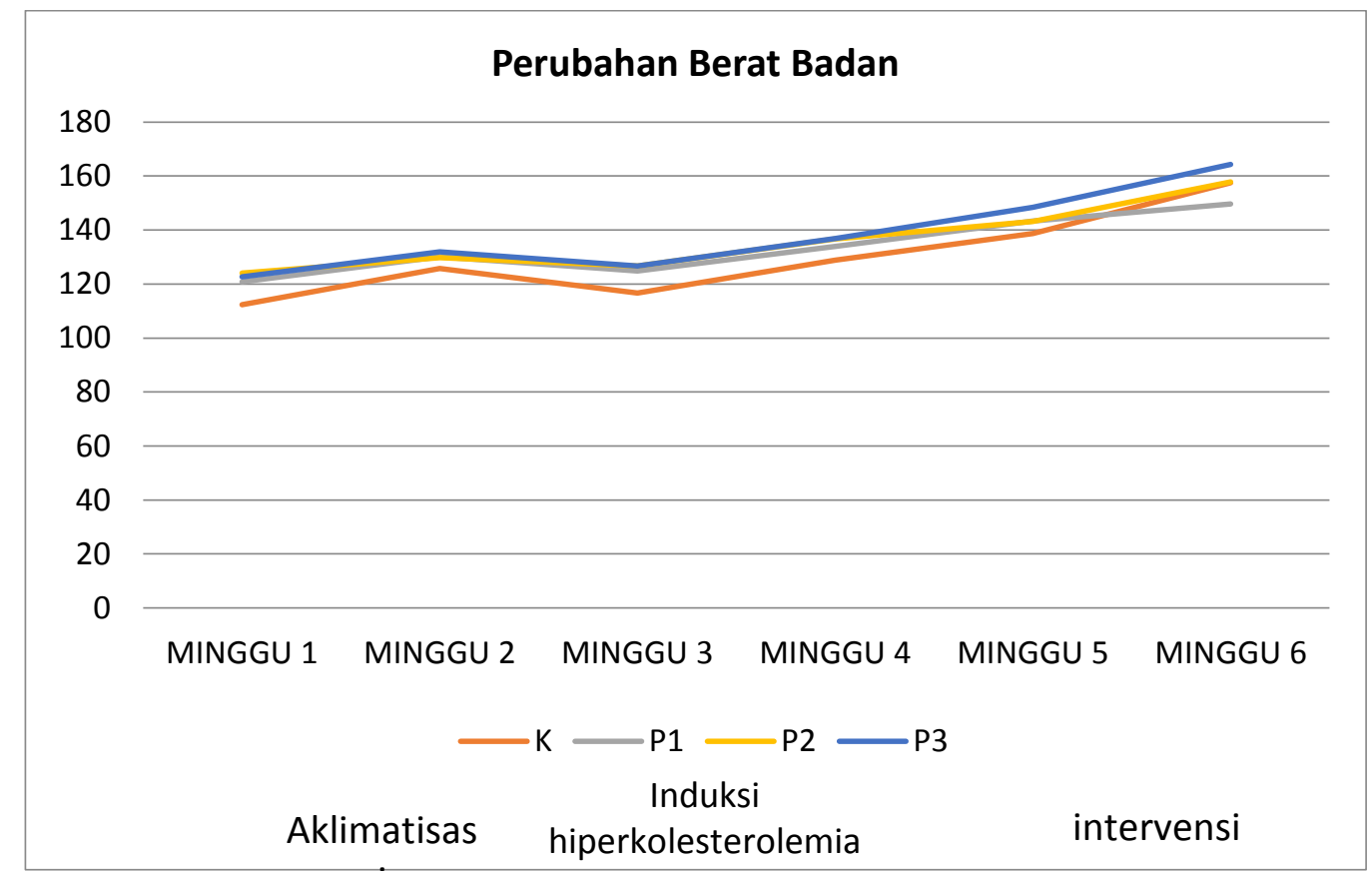

Grafik 1. Perubahan Berat Badan Tikus Coba selama penelitian

Grafik 1 menunjukkan bahwa sampel pada kelompok kontrol maupun perlakuan mengalami kenaikan berat badan selama penelitian. Pada awal tahap induksi hiperkolesterolemia (minggu ke-3), berat badan sampel pada kelompok kontrol maupun perlakuan cenderung turun dan mengalami kenaikan kembali pada tahap akhir induksi hiperkolesterolemia hingga tahap intervensi.

Berat badan sampel setiap kelompok sebelum dan setelah intervensi dianalisis dengan $u j i$ paired t-test dengan hasil pada tabel 1

Tabel 1. Rerata Berat Badan Sampel Sebelum (setelah induksi hiperkolesterolemia) dan Setelah Intervensi

\begin{tabular}{lccc}
\hline Kelompok & Sebelum & Setelah & P \\
\cline { 2 - 3 } & Rerata \pm SD & Rerata \pm SD & \\
\hline K & $128,83 \pm 11,30$ & $157,50 \pm 11,30$ & $0.002^{\mathrm{a}^{*}}$ \\
P1 (jus pare) & $134,00 \pm 13,44$ & $156,67 \pm 13,30$ & $0,008^{\mathrm{a}^{*}}$ \\
P2 (jus jeruk) & $136,67 \pm 10,80$ & $158,50 \pm 17,73$ & $0,017^{\mathrm{a}^{*}}$ \\
P3(jus pare+jeruk) & $136,83 \pm 12,61$ & $164533 \pm 12,61$ & $0,046^{\mathrm{a}^{*}}$ \\
\hline & \multicolumn{2}{c}{ Anova $\Delta P$} & 0,384 \\
\hline
\end{tabular}

${ }^{a}$ paired $t$-test ${ }^{*}$ beda bermakna

Tabel 1 menunjukkan bahwa rerata berat badan pada kelompok kontrol, P1, P2, P3 mengalami kenaikan secara bermakna $(\mathrm{p}<0,05)$. Uji Statistik pada perubahan berat badan antar kelompok menunjukkan bahwa tidak ada perbedaan perubahan berat badan antar kelompok yang bermakna $(\mathrm{p}>0,05)$. 

penelitian ditunjukkan pada grafik 2 dibawah ini

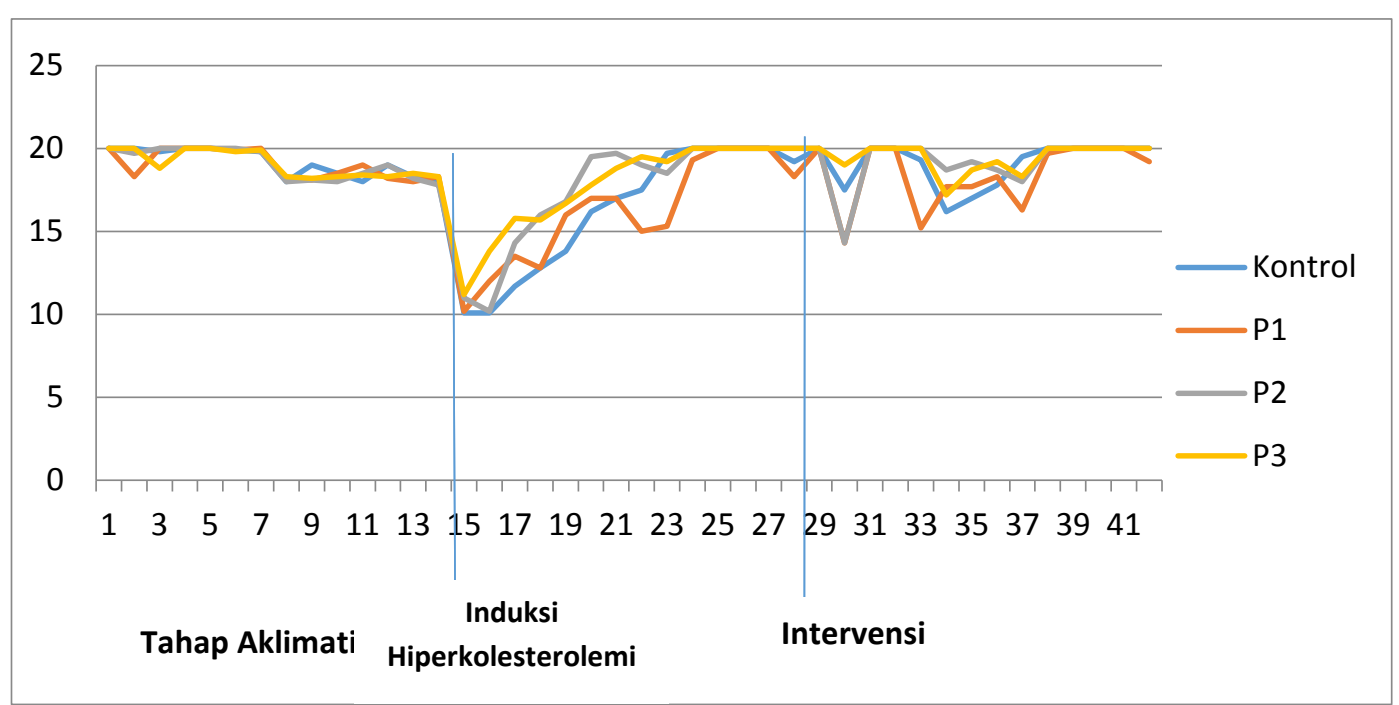

Grafik 2. Perubahan rerata asupan pakan selama penelitian

Grafik 2 menunjukkan rerata asupan pakan setelah semua kelompok tetapi mengalami kenaikan induksi hiperkolesterolemia cenderung turun pada kembali selama tahap intervensi.

Tabel 2. Rerata Asupan Pakan Sebelum (setelah induksi hipekrolesterolemia) dan Setelah Intervensi

\begin{tabular}{|c|c|c|c|c|}
\hline \multirow{2}{*}{ Kelompok } & & Setelah & \multirow{2}{*}{$\begin{array}{c}\Delta \\
\text { (gram) }\end{array}$} & \multirow{2}{*}{$\mathbf{P}$} \\
\hline & Rerata \pm SD & Rerata \pm SD & & \\
\hline $\mathrm{K}$ & $16,33 \pm 1,28$ & $19,08 \pm 0,83$ & 2,75 & $0,002^{\mathrm{a}}$ \\
\hline P1 (Jus Pare) & $16,35 \pm 1,77$ & $18,43 \pm 0,48$ & 2,08 & $0,015^{\mathrm{a}}$ \\
\hline P2(Jus jeruk) & $16,85 \pm 1,48$ & $18,85 \pm 0,87$ & 2,00 & $0,002^{\mathrm{a}^{*}}$ \\
\hline \multirow[t]{2}{*}{ P3 (Pare+Jeruk) } & $17,3 \pm 1,59$ & $19,46 \pm 0,45$ & 2,15 & $0,007^{a^{*}}$ \\
\hline & Anova $\Delta P$ & & & 0,931 \\
\hline
\end{tabular}

paired t-test *beda bermakna

Tabel 2 menunjukkan bahwa rerata asupan pakan pada semua kelompok selama tahap intervensi lebih tinggi dibandingkan tahap induksi hiperkolesterolemia $(\mathrm{p}<0,05)$. Kenaikan rerata asupan pakan pada setiap kelompok bervariasi dengan kenaikan tertinggi terjadi pada kelompok kontrol sebesar 2,75 gram, kelompok P1 2,08 gram, P2 2,00 gram dan kelompok P3 2,15 gram. Namun secara statistik, tidak ada perbedaan bermakna kenaikan asupan pakan antar kelompok ( $>00,05)$.

Kadar Kolesterol Total Sebelum dan Setelah Induksi Hiperkolesterolemia

Tabel 3. Rerata Kadar Total Sebelum dan Setelah Induksi Hiperkolesterolemia

\begin{tabular}{|c|c|c|c|c|c|}
\hline \multirow[t]{2}{*}{ Kelompok } & \multirow[b]{2}{*}{$\mathbf{N}$} & Sebelum & \multirow{2}{*}{$\begin{array}{c}\text { Setelah } \\
\text { Rerata } \pm \text { SD }\end{array}$} & \multirow{2}{*}{$\begin{array}{c}\Delta \\
(\mathrm{mg} / \mathrm{dL})\end{array}$} & \multirow[t]{2}{*}{$\mathbf{P}$} \\
\hline & & Rerata \pm SD & & & \\
\hline $\mathrm{K}$ & 6 & $66,56 \pm 6,23$ & $91,54 \pm 4,41$ & 24,98 & $0,000^{\mathrm{a}^{*}}$ \\
\hline P1 (Jus Pare) & 6 & $63,29 \pm 10,18$ & $86,56 \pm 1,34$ & 23,27 & $0,001^{\mathrm{a}^{*}}$ \\
\hline P2(Jus jeruk) & 6 & $69,66 \pm 14.73$ & $101,08 \pm 16,9$ & 31,42 & $0,001^{\mathrm{a}^{*}}$ \\
\hline P3 (Pare+Jeruk) & 6 & $72,99 \pm 4,5$ & $92,68 \pm 9,88$ & 19,68 & $0,007^{a^{*}}$ \\
\hline \multicolumn{4}{|c|}{ Anova $\Delta P$} & & 0,174 \\
\hline
\end{tabular}

\section{${ }^{a}$ paired $t$-test ${ }^{*}$ beda bermakna}

Setelah induksi hiperkolesterolemia, kadar kolesterol total pada semua kelompok mengalami kenaikan dan mencapai kondisi hiperkolesterolemia (normal $10-54 \mathrm{mg} / \mathrm{dL})^{19}$ yang bermakna secara statistik $(\mathrm{p}<0,05)$. Perbedaan kenaikan kadar kolesterol total antar kelompok dianalisis dengan uji one way anova menunjukkan bahwa tidak ada perbedaan kenaikan kadar kolesterol total antar kelompok ( $>>0,05)$. 


\section{Kadar Kolesterol Total Sebelum dan Setelah Intervensi}

Tabel 4. Rerata Kadar Kolesterol Total Sebelum dan Setelah Intervensi

\begin{tabular}{lcccccc}
\hline \multicolumn{1}{c}{ Kelompok } & N & $\begin{array}{c}\text { Sebelum } \\
\text { Rerata } \pm \text { SD }\end{array}$ & $\begin{array}{c}\text { Setelah } \\
\text { Rerata } \pm \text { SD }\end{array}$ & $\begin{array}{c}\Delta \\
(\mathbf{m g} / \mathbf{d L})\end{array}$ & $\begin{array}{c}\text { Persen } \Delta \\
(\boldsymbol{\%})\end{array}$ & P \\
\hline K & 6 & $91,54 \pm 4,41$ & $75,65 \pm 12,27$ & $15,89 \pm 11,4$ & 17,35 & $0,019^{\mathrm{b}^{*}}$ \\
P1 (Jus Pare) & 6 & $86,56 \pm 1,34$ & $67,07 \pm 9,18$ & $19,48 \pm 2,51$ & 22,51 & $0,00^{\mathrm{b}^{*}}$ \\
P2(Jus jeruk) & 6 & $101,08 \pm 16,9$ & $71,83 \pm 13,3$ & $29,24 \pm 11,93$ & 28,93 & $0,002^{\mathrm{b}^{*}}$ \\
P3 (Pare+Jeruk) & 6 & $92,68 \pm 9,88$ & $73,53 \pm 9,18$ & $19,12 \pm 9,21$ & 24,04 & $0,004^{\mathrm{b}^{*}}$ \\
\hline \multicolumn{7}{c}{ Anova $\Delta \boldsymbol{P}$} \\
\hline
\end{tabular}

${ }^{a}$ Uji One Way ANOVA ${ }^{b}$ paired t-test *beda bermakna

Tabel 5 menunjukkan bahwa terjadi penurunan kolesterol total pada semua kelompok perlakuan setelah pemberian jus pare, jus jeruk nipis dan kombinasi jus pare+jeruk nipis. Penurunan terbesar terjadi pada kelompok perlakuan yang diberi jus jeruk nipis dengan presentase sebesar $28,93 \%$. Presentase penurunan kolesterol total pada pemberian kombinasi jus pare+jeruk nipis $(24,04 \%)$ lebih tinggi dibandingkan kelompok yang hanya diberi jus pare saja $(22,51 \%)$. Penurunan kolesterol total juga dialami kelompok kontrol dengan presentase penurunan lebih rendah dibandingkan kelompok perlakuan yaitu sebesar $17,35 \%$.

Hasil uji paired $t$-test menunjukkan adanya perbedaan bermakna antara kolesterol total sebelum dan setelah pemberian intervensi dengan $p<0,05$. Namun analisis statistik pada perubahan rerata kolesterol total antar kelompok menunjukkan tidak ada perbedaan bermakna dengan $p=0,105(p>0,05)$. Hasil uji statistik perubahan rerata kolesterol total antara kelompok kontrol dengan kelompok $\mathrm{P} 1, \mathrm{P} 2, \mathrm{P} 3$ juga tidak menunjukkan perbedaan yang bermakna ( $p=0,619, p=0,057, p=0,803)$ sehingga dapat disimpulkan bahwa pemberian jus pare $2 \mathrm{ml}$, jus jeruk nipis $2 \mathrm{ml}$ dan kombinasi jus pare+jeruk nipis $4 \mathrm{ml}$ tidak menunjukkan pengaruh yang nyata terhadap penurunan kadar kolesterol total $(p>0,05)$.

\section{PEMBAHASAN}

\section{Perubahan Asupan Pakan dan Berat Badan Selama Penelitian}

Rerata asupan pakan antar kelompok selama penelitian tidak menunjukkan perbedaan. Rerata asupan pakan standar pada semua kelompok selama tahap induksi hiperkolesterolemia cenderung turun dibandingkan pada tahap aklimatisasi. Penurunan asupan pakan ini kemungkinan disebabkan pakan tinggi kolesterol yang diberikan dapat memperlambat waktu pengosongan lambung pada tikus sehingga tikus mengasup pakan standar lebih sedikit bila dibandingkan pada tahap aklimatisasi. Hasil penelitian ini sesuai dengan penelitian sebelumnya bahwa pemberian diet tinggi kolesterol cenderung menurunkan asupan pakan standar tikus coba. ${ }^{21}$

Berat badan sampel pada semua kelompok mengalami kenaikan selama penelitian. Namun beberapa sampel mengalami penurunan berat badan selama tahap awal induksi hiperkolesterolemia. Hal tersebut kemungkinan karena faktor stres yang dialami hewan coba. Respon terhadap stres ini dapat ditunjukkan dengan perubahan berat badan dan hormonal yaitu hormon kortikosteron. ${ }^{22,23}$ Stres pada hewan coba ini dapat disebabkan karena tindakan yang dilakukan saat penelitian seperti cara pemegangan, pengambilan darah, pengukuran berat badan, proses penyondean, pengandangan individu, dan pembersihkan kandang. ${ }^{23}$ Penurunan berat badan kemungkinan terjadi karena adanya peningkatan kadar hormon kortikosteron yang menginduksi perubahan cadangan glukosa dan lemak untuk penyediaan sumber energi metabolisme yang digunakan dalam merespon stres sehingga memungkinkan terjadinya penurunan berat badan pada tikus. ${ }^{22}$

\section{Kadar Kolesterol Total Setelah Pemberian Pakan Tinggi Kolesterol}

Hasil penelitian menunjukkan kolesterol total pada semua kelompok perlakuan mengalami kenaikan secara signifikan setelah pemberian pakan tinggi kolesterol selama 14 hari. Hasil ini sesuai dengan penelitian sebelumnya bahwa pemberian otak sapi selama 21 hari pada tikus sprague dawley dapat meningkatkan kadar kolesterol total signifikan hingga $70,45 \% .^{20}$

Bubur otak sapi yang diberikan pada hewan coba berasal dari otak sapi kukus yang telah dihaluskan dengan penambahan air untuk mempermudah pemberian dengan cara sonde dengan dosis sebanyak $2 \mathrm{ml} / \mathrm{ekor} /$ hari. Kandungan 100 gram otak sapi terdiri dari kolesterol $3100 \mathrm{mg}$, asam lemak jenuh 2 gram, asam lemak trans 1 gram. ${ }^{24}$ Asupan asam lemak jenuh dan kolesterol memiliki korelasi positif dengan meningkatnya 
kadar kolesterol total dan kadar kolesterol LDL dengan menurunkan reseptor LDL serta meningkatkan pembentukan LDL plasma dengan menurunkan efek turnover LDL kolesterol. ${ }^{25}$

\section{Pengaruh Jus Pare , Jus Jeruk Nipis dan Kombinasi Kedua Jus terhadap Kadar Kolesterol Total}

Hasil analisis statistik menunjukkan bahwa pemberian jus pare $2 \mathrm{ml}$, jus jeruk nipis $2 \mathrm{ml}$ dan kombinasi jus pare+jeruk nipis $4 \mathrm{ml}$ selama 14 hari tidak menunjukkan pengaruh yang nyata terhadap penurunan kadar kolesterol total tikus coba $(p>0,05)$. Tidak ada perbedaan bermakna rerata perubahan kadar kolesterol total antar kelompok kontrol dan perlakuan setelah pemberian jus pare, jus jeruk nipis dan jus pare+jeruk nipis. Pada penelitian ini selain kelompok perlakuan, kolesterol total pada kelompok kontrol yang tidak diberi intervensi juga mengalami penurunan sebesar $17,53 \%(p<0,05)$.

Kadar kolesterol dalam tubuh dapat dipengaruhi antara lain usia, jenis kelamin, genetik, asupan, berat badan, hormon dan stres. Dalam penelitian ini faktor usia, jenis kelamin dan galur tikus coba telah dikendalikan dengan menggunakan tikus dengan usia, jenis kelamin dan galur yang sama yaitu tikus jantan Sprague Dawley dengan usia 8 minggu. Faktor lain yang tidak dapat dikendalikan adalah stres dan hormonal.

Selama tahap intervensi, semua kelompok hanya diberi pakan standar dan tidak diberi pakan tinggi kolesterol. Penghentian pemberian pakan tinggi kolesterol ini berpengaruh terhadap kadar kolesterol total. ${ }^{26}$ Kandungan lemak jenuh dalam pakan standar kemungkinan lebih rendah dibandingkan pakan tinggi kolesterol sehingga pergantian jenis pakan dengan pakan standar saja diduga mampu menurunkan kadar kolesterol total meskipun tidak diberi intervensi.

Penurunan kolesterol total pada kelompok kontrol diduga juga disebabkan penurunan faktor penyebab stres pada tikus coba. Selama intervensi tidak dilakukan penyondean pada kelompok kontrol yang diduga terjadi penurunan stress pada tikus coba. Stres pada tikus coba dapat terjadi karena proses penyondean, cara pemegangan, pengambilan darah, pengukuran berat badan. ${ }^{23}$ Keadaan stres dapat berpengaruh terhadap kadar kolesterol dengan memacu produksi hormon epinefrin, norepinefrin, dan glukokortikoid yang akan mengaktifkan hormon peka lipase untuk memecah simpanan triasilgliserol dan meningkatkan asam lemak bebas di dalam plasma. ${ }^{23,27}$

Faktor teknis seperti seperti cara pengambilan darah yang kurang tepat, cara memasukkan sampel darah ke dalam tabung yang kurang tepat, penyimpanan sampel yang kurang tepat saat dibawa ke tempat pengujian kemungkinan mempengaruhi hasil uji laboratorium kolesterol total pada penelitian ini. ${ }^{28,29}$

Meskipun secara statistik tidak ada perbedaan signifikan rerata perubahan kadar kolesterol total antar kelompok, tetapi ada perbedaan presentase penurunan kolesterol total setelah pemberian intervensi antar kelompok. Penurunan kolesterol total oleh jus jeruk nipis sebesar $28,93 \%$, jus pare $22,51 \%$ dan jus kombinasi pare+jeruk nipis sebesar $24,04 \%$. Presentase penurunan kolesterol total oleh kombinasi jus pare+jeruk yang diduga mampu menurunkan kadar kolesterol total paling signifikan ternyata belum menunjukkan hasil yang diharapkan. Presentase penurunan kolesterol total oleh kombinasi jus pare+jeruk lebih rendah dibandingkan jus jeruk nipis tetapi lebih tinggi dibandingkan pemberian jus pare saja. Hasil penelitian ini belum sesuai dengan penelitian sebelumnya bahwa kombinasi bahan makanan yang memilki aktivitas hipokolesterolemik mampu menurunkan kadar kolesterol total lebih signifikan. Hasil penelitian ini tidak sejalan dengan penelitian sebelumnya pada kombinasi jus jeruk lemon+jeruk nipis yang mampu menurunkan kadar kolesterol total lebih tinggi dibandingkan jus jeruk lemon dan jus jeruk nipis saja. ${ }^{17}$ Hal tersebut diduga disebabkan karena waktu intervensi yang kurang lama sehingga efek hipokolesterolemik kombinasi jus pare+jeruk nipis tersebut belum bekerja optimal.

Salah satu mekanisme kombinasi jus pare+jeruk nipis yang diduga mampu menurunkan kolesterol total yaitu dengan peran buah pare yang meningkatkan aktivitas cholesterol $7 \alpha$-hydroxylase (CYP7A1) dalam mengkonversi kolesterol menjadi asam empedu. Peningkatan tersebut berdampak pada peningkatan jumlah reseptor LDL dan penurunan aktivitas HMG KoA reduktase dalam sintesis kolesterol di hati yang juga kemungkinan dipengaruhi oleh hesperidin dalam jeruk nipis yang mampu menghambat kerja HMG KoA reduktase dan meningkatkan konsentrasi reseptor LDL. ${ }^{12,27}$ Selain itu, vitamin $\mathrm{C}$ dalam buah jeruk nipis dan pare dapat membantu dalam metabolisme kolesterol dengan cara meningkatkan laju pembuangan lemak dalam bentuk asam empedu dan membantu reaksi hidroksilasi dalam pembentukan asam empedu sehingga meningkatkan ekskresi kolesterol dari dalam tubuh. ${ }^{10,13,14}$

Pemberian jus jeruk nipis menunjukkan penurunan kolesterol total tertinggi $(28,93 \%)$ dibandingkan perlakuan lain. Hasil penelitian ini sejalan dengan penelitian sebelumnya yang 
dilakukan pada tikus wistar hiperkolesterolemia dengan rerata kolesterol total $236 \mathrm{mg} / \mathrm{dL}$ yang diberi jus jeruk nipis $1 \mathrm{ml} /$ hari selama 7 hari dimana terjadi perbedaan rerata kolesterol total akhir pada kelompok kontrol $(269,2 \pm 22,5 \mathrm{mg} / \mathrm{dL})$ dan kelompok perlakuan $(105,5 \pm 8,5 \mathrm{mgdL}) .{ }^{28}$ Aktivitas hipokolesterolemik ini kemungkinan berhubungan dengan kandungan flavanon utama dalam jeruk yaitu hesperidin, naringenin dan vitamin $\mathrm{C}$ dalam jeruk nipis. Hesperidin merupakan flavonoid utama pada jeruk manis, jeruk nipis, lemon dan pada bulir-bulir jeruk. ${ }^{31}$ Mekanisme kerja hesperidin yaitu melalui penghambatan aktifitas enzim yang berperan dalam metabolisme kolesterol yaitu Hesperidin menghambat produksi kolesterol dengan cara menghambat kerja enzim 3hydroxy-3-methylglutaryl coenzim A-reductase dalam sintesis kolesterol. ${ }^{30,31}$ Penghambatan aktivitas enzim HMG-KoA reduktase sangat efektif untuk menurunkan kadar kolesterol. ${ }^{17,31}$ Enzim ini bekerja pada tahap regulatorik utama di jalur sintesis kolesterol dengan mengkatalis proses reduksi HMG-KoA menjadi mevalonat oleh NADPH. Proses ini menjadi sasaran kerja golongan obat penurun kadar kolesterol yang efektif seperti statin. ${ }^{17}$ Kandungan vitamin $C$ dalam jus jeruk nipis dapat membantu dalam metabolisme kolesterol dengan cara meningkatkan laju pembuangan lemak dalam bentuk asam empedu dan membantu reaksi hidroksilasi dalam pembentukan asam empedu sehingga meningkatkan ekskresi kolesterol dari dalam tubuh..$^{31,13}$

Buah pare mampu meningkatkan akivitas enzim cholesterol $7 \alpha$-hydroxylase (CYP7A1) dalam mengkonversi kolesterol menjadi asam empedu. Penelitian oleh Oishi et al menunjukkan bahwa saponin dalam ekstrak buah pare mampu mengikat kolesterol yang dapat menurunkan kontak langsung antara kolesterol dengan enzim lipase. Hal tersebut secara tidak langsung dapat menghambat aktivitas enzim lipase yang kemudian dapat menurunkan penyerapan lemak dalam usus halus. ${ }^{32}$ Lektin pada kulit pare dapat menghambat ambilan trigliserol dari diet oleh kilomikron di dalam dinding usus, selanjutnya dapat menurunkan absorpsi

\section{SIMPULAN}

Tidak terdapat perbedaan pengaruh pemberian jus pare $2 \mathrm{ml}$, jus jeruk nipis $2 \mathrm{ml}$ dan kombinasi jus pare+jeruk nipis $4 \mathrm{ml}$ selama 14 hari terhadap penurunan kadar kolesterol total tikus sprague dawley hiperkolesterolemia.

\section{SARAN}

Perlu dilakukan analisis kandungan zat-zat hipokolesterolemik jus pare, jeruk nipis dan kombinasi jus pare+jeruk nipis. Pemberian intervensi melalui sonde perlu dilakukan pada semua kelompok selama intervensi sehingga tingkat stres dapat dikendalikan. Pemberian intervensi pada tikus coba sebaiknya dilakukan dalam jangka waktu lebih lama (> 14 hari) sehingga dapat diperoleh penurunan kolesterol yang lebih signifikan.

\section{DAFTAR PUSTAKA}

1. Adam JMF. Dislipidemia dalam SudoyoAW, Setiyohadi B, Alwi I, K. Marcellus S, Setiati S. Ilmu Penyakit Dalam. Edisi V Jilid III. Jakarta: Interna Publishing;2009.hal.1984;92

2. Third Report of the National Cholesterol Education Program (NCEP) Expert Panel on Detection, Evaluation and Treatment of High Blood Cholesterol in Adult (Adult Panel Treatment Panel III). National Heart, Lung and Blood Institue. National Intitutes of Health. 2002:NIH Publication.

3. Hatma. R.D. Sosial Determinan dan Faktor Risiko Kardiovaskuler (Analisi Data Sekunder Riskesdas 2007). Buletin Jendela Data dan Informasi Kesehatan. 2011;2:15-22

4. World Health Organization. Global Status Report On Noncommunicable Diseases 2010. Geneva.2011

5. Roth GA., Fihn SD., Mokdad AH., et al. High Total Serum Cholesterol, Medication Coverage And Therapeutic Control: An Analysis Of National Health Examination Survey Data From Eight Countries. Bull World Health Organization; 2011 ; 89:92-101

6. Anwar T.B. Dislipidemia sebagai faktor risiko penyakit jantung koroner.e-USU Repository Universitas Sumatera Utara. 2009:1-10

7. Reiner Z, et al. ESC/EAS Guidlines For The Management of Dyslipidemias. The Task Force for The Management of Dyslipidemia of European Society of Cardiology (ESC) and the European

8. Kementrian Kesehatan Republik Indonesia. Riset Kesehatan Dasar Indonesia 2013.

9. Grover J.K, Yadav S.P. Pharmacological Actions And Potential Uses of Mommordica Charantia : A Review. Journal of Ethnopharmacology.2004;93:123-32

10. Dey SS, Behera TK, Charanjeet K. Genetic Variability In Ascorbic Acid and Carotenoids Content in Indian Bitter Gourd (Momordica charantia L.) Germplasm. 2005. Cucurbit Genetics Cooperative (No.28/29)

11. Nurhaeni A,Surastri B. Pengaruh Pemberian Jus Buah Pare (Momordica Charantia) Dosis Bertingkat Terhadap Kenaikan Kadar Kolesterol Total Serum Tikus Jantan Galur Wistar Yang Diberi Pakan Tinggi Lemak [Karya Tulis Ilmiah].Semarang. Universitas Diponegoro ; 2008 
12. Matsui S, Yamane T, Takita T, Oishi Y, Hattori KK. The Hypocholesterolemic Activity of Momordica Charantia Fruit is Mediated by The Altered Cholesterol-And Bile-Acid-Regulating Gene Expression in Rat Liver.Nutrition Research. 2013 : 580-85

13. Aptekman N.P, Cesar T.B. Long-Term Orange Juice Consumption is Associated With Low LDLCholedterol And Apolipoprotein B In Normal And Moderately Hypercholesterolemic Subjects. Biomed Central. 2013: 1-10

14. Aptekman N.P, Cesar T.B. Orange Juice Improved Lipid Profile and Blood Lactat of Overweight Middle-Aged Women Subjected to Aerobic Training. Food and Nutrition Department, Faculty of Pharmaceutical Science ; Maturitas (67) : 34347

15. Peterson JJ et al. Flavanone in grapefruit, lemons, and limes: A Compilation and Review of The Data From The Analytical Literature. Journal of Food Composition and Analysis.2006:74-80

16. Bostham M,Asgary S, Mostaghian J, Naderi G, Jafari-Dinani N. Impact of Fresh Lime Juice and Peel on Atherosclerosisi Progression in An Animal Model. Arya Artheroscler.2012;9(6);357-62

17. Ajugwo A.O et al. Nutritional Value of Lime and Lemon in Hypercholesterolaemic Induced Rats. Asian Journal of Medical Science;2012:13-16

18. Doucet C, Flament C, Sautier C, Lemonnier D. Effect of an Hypercholesterolemic Diet on The Level of Several Serum Lipids and Apolipoproteins in Nine Rat Strains. Journal of Animal Research and Animal Science (Formerly: Reproduction Nutrition Development). 1987;27(5):897-906.

19. Throne Research Inc. Momordica Charantia. Alternative Medicine Review.2007;12(4):360-63

20. Riyanto S, Murwani H. Pengaruh Pemberian Yoghurt Kedelai Hitam (Black Soyguhrt) Terhadap Profil Lipid Tikus Hiperkolesterolemia. [Skripsi]. Universitas Diponegoro. Semarang ; 2011

21. Tsalissavrina, Iva. 2006. Pengaruh Pemberian Diet Tinggi Karbohidrat dibandingkan Diet Tinggi Lemak terhadap Kadar Trigliserida dan HDL Darah pada Rattus novergicus Galur Wistar. Jurnal Kedokteran Brawijaya, Vol. XXII, No.2

22. Ridwan Ahmad, Zuliyanto Zakaria, dan Anggraini Barlian. Pengaruh Fotoperiode terhadap Respons Stres dan Parameter Repoduksi pada Mencit Jantan (Mus musculus L.) Galur Wistar Webster. Jurnal Matematika dan Sains, 2012:17(1).

23. Balcombe, JP., Bernard, ND., et al. Laboratory Rountines Cause Animal Stress. American Association for Laboratory Animal Science;2004: 43;6

24. Condé Nast. Nutrition Facts: Beef, variety meats and by-products, brain, cooked, simmered. [cited 2014 September 5]. Available from URL: http://nutritiondata.self.com/facts/beefproducts $/ 3463 / 2$
25. Witradharma T.W, Lipoeto N.I, Asri Aswiyanti. Pengaruh Konsumsi Berbagai Jensi Asam Lemak terhadap Indikator Kejadian Aterogenesis pada Tikus Jantan Strain Wistar.[Karya Tulis Ilmiah]. Padang.Universitas Andalas;2010

26. Gill JMR, Brown JC, et al. Effects Of Dietary Monosaturated Fatty Acid on Lipoprotein Concentration Composition And Subbfraction Distribution and On VLDL Apoliprotein B Kinetic: Dose-Dependent Effect On LDL. Am J Clin Nutr. 2003;78;47-56

27. Botham KM, Mayes PA. Sintesis, Transpor dan Ekskresi kolesterol. In : Murray RK,Graner DK, Mayes PA, Rodwell VW, editor. Biokimia Harper. $27^{\text {th }}$ ed. Jakarta : Penerbit Buku Kedokteran EGC ; 2006.p.239- 49

28. Harvey, J. W. 2001. Atlas of Veterinary Hematology : Blood and Bone Marrow of Domestic Animals. W.B. Saunders Company, USA.

29. Badan Lingkungan Hidup. Jaminan Mutu dan Pengendalian Mutu Hasil Uji Laboratorium. [cited 2014 September 19]. Availablefrom URL : http://blh.jogjaprov.go.id/2013/01/jaminan-mutudan-pengendalian-mutu-hasil-uji-laboratorium/

30. Akiyama A, Katsumata A, Suzuki K, Ishimi Y, Wu J, Uehara M. Hesperidin Exerts Hypoglicemic and Hypolipidemic Effect in Streptozotocin-Induced Marginal Type 1 Diabetic Rats. J Clin.Biochem. Nutr. 2010;46:87-92.

31. Garg A, Garg S, Zaneveld J D, Singla A K. Chemistry and Pharmacology of The Citrus Bioflavonoid Hesperidin. Phytother. Res. 2001;15:655-69

32. Oishi $Y$, Sakamoto $\mathrm{T}$, Udagawa $\mathrm{H}$, et al. Inhibition Of Increases In Blood Glucose And Serum Neutral Fat By Momordica Charantia Saponin Fraction. Biosci Biotechnol Biochem.2007;71:735-40

33. Lamanepa M.E.L. Perbandingan Profil Lipid dan Perkembangan Lesi Aterosklerosis pada Tikus Wistar Yang Diberi Perasan Pare dengan Diet Perasan Pare dan Statin [Tesis] Magister Ilmu Biomedik. Universitas Diponegoro Semarang ; 2005. 